\title{
Pairwise structural comparison of tiagabine analogs gives new insights into their protein binding modes
}

\author{
Barbara Zdrazil $^{1^{*}}$, Andreas Jurik ${ }^{1}$, Harald H Sitte ${ }^{2}$, Gerhard F Ecker ${ }^{1}$ \\ From 8th German Conference on Chemoinformatics: 26 CIC-Workshop \\ Goslar, Germany. 11-13 November 2012
}

Tiagabine (Gabitril ${ }^{\circledR}$ ) is a selective inhibitor of the human gamma-aminobutyric acid (GABA) transporter 1 (hGAT-1), a transport protein belonging to the family of neurotransmitter-sodium-symporters (NSS). It is a marketed drug, used for treatment of epilepsy. However, the molecular basis of protein-ligand interaction remains obscure due to the lack of a 3D structure of the target protein.

In order to identify activity-determining structural features of a series of tiagabine analogs taken from literature [1-3], we chose an approach combining traditional methods of molecular modeling with exhaustive sampling of docking poses, and a pairwise comparison of structural features and their respective bioactivity values.

We determined a common binding mode of tiagabine analogs, which is in nice agreement with literature [4]. Further, we were able to trace back considerable differences in inhibitory activities to distinct molecular attributes of the analogs.

Our study revealed the molecular explanation for the importance of a polar linker region and thus paves the way for subsequent screening efforts in the search for novel GAT-1 inhibitors.

\section{Author details}

'University of Vienna, Department of Medicinal Chemistry, Althanstrasse 14, Vienna, A-1090, Austria. ${ }^{2}$ Medical University of Vienna, Institute of Pharmacology, Vienna, A-1090, Austria.

Published: 22 March 2013

\footnotetext{
* Correspondence: barbara.zdrazil@univie.ac.at

'University of Vienna, Department of Medicinal Chemistry, Althanstrasse 14, Vienna, A-1090, Austria

Full list of author information is available at the end of the article
}

\section{References}

1. Andersen $\mathrm{KE}$, et al: The synthesis of novel GABA uptake inhibitors. 1. Elucidation of the structure-activity studies leading to the choice of (R)-1-[4,4-bis(3-methyl-2-thienyl)-3-butenyl]-3-piperidinecarboxylic acid (tiagabine) as an anticonvulsant drug candidate. J Med Chem 1993, 36:1716-1725.

2. Knutsen $\sqcup$, et al: Synthesis of novel GABA uptake inhibitors. 3. Diaryloxime and diarylvinyl ether derivatives of nipecotic acid and guvacine as anticonvulsant agents. J Med Chem 1999, 42:3447-3462.

3. Andersen KE, et al: Synthesis of novel GABA uptake inhibitors. 4. Bioisosteric transformation and successive optimization of known GABA uptake inhibitors leading to a series of potent anticonvulsant drug candidates. J Med Chem 1999, 42:4281-4291.

4. Skovstrup, et al: Homology modelling of the GABA transporter and analysis of tiagabine binding. Chem Med Chem 2010, 5:986-1000.

doi:10.1186/1758-2946-5-S1-P32

Cite this article as: Zdrazil et al.: Pairwise structural comparison of tiagabine analogs gives new insights into their protein binding modes. Journal of Cheminformatics 2013 5(Suppl 1):P32.

\section{Publish with ChemistryCentral and every scientist can read your work free of charge \\ "Open access provides opportunities to our colleagues in other parts of the globe, by allowing anyone to view the content free of charge." \\ W. Jeffery Hurst, The Hershey Company. \\ - available free of charge to the entire scientific community \\ - peer reviewed and published immediately upon acceptance \\ - cited in PubMed and archived on PubMed Central \\ - yours - you keep the copyright \\ Submit your manuscript here: \\ http://www.chemistrycentral.com/manuscript/

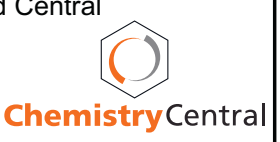

